ENTREPRENEURSHIP AND SUSTAINABILITY ISSUES

ISSN 2345-0282 (online) http://jssidoi.org/jesi/ 2019 Volume 7 Number 1 (September)

http://doi.org/10.9770/jesi.2019.7.1(47)

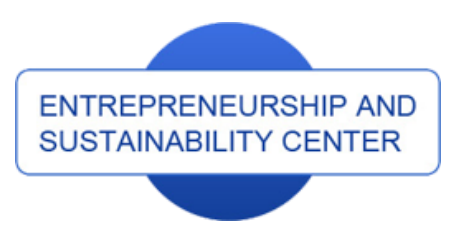

Publisher

http://jssidoi.org/esc/home

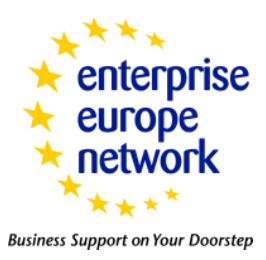

CASPA

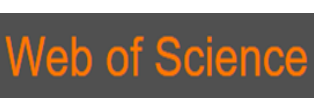

Clarivate
Analytics

\title{
SUSTAINABLE TERRITORIAL DEVELOPMENT BASED ON THE EFFECTIVE USE OF RESOURCE POTENTIAL
}

\section{Olga Voronkova ${ }^{1}$, Veronika Yankovskaya ${ }^{2}$, Irina Kovaleva ${ }^{3}$, Ilya Epishkin ${ }^{4}$, Iuliana Iusupova ${ }^{5}$, Yuliya Berdova ${ }^{6}$}

\author{
${ }^{1}$ Altai state University, Lenina Str. 61, Barnaul, Russian Federation \\ ${ }^{2}$ Plekhanov Russian University of Economics (PRUE), Stremyanny Lane 36, 117997, Moscow, Russian Federation \\ ${ }^{3}$ Altai State Agricultural University, Prospect Krasnoarmeyskiy, 98, Barnaul, Russian Federation \\ ${ }^{4}$ Russian University of Transport, 127055, Str. Obraztsova 9, p. 9, Moscow, Russian Federation \\ ${ }^{5}$ I.M. Sechenov First Moscow State Medical University, Moscow, Russian Federation \\ ${ }^{6}$ Industrial University of Tyumen, Volodarskogo Str. 38, 625000, Tyumen, Russian Federation \\ E-mails:1olka2004@yandex.ru ; ${ }^{2}$ veronika28-2@mail.ru; ${ }^{3}$ irakovaleva20051@ rambler.ru; \\ ifo@ rut-miit.ru, ${ }^{5}$ 1870221@mail.ru, ${ }^{6}$ bjordovajs@tyuiu.ru
}

Received 12 March 2019; accepted 30 July 2019; published 30 September 2019

\begin{abstract}
The effective use of resource potential is a prerequisite for implementing all the functions of the territory and thus, can be considered fundamental for sustainable territorial development. Within the context of the current crisis in the economic sphere, regional affiliation generally occupies a special place in the structure of socio-economic development. Therefore, finding ways to ensure the effective use of resource potential is a crucial task, combining territorial specifics with the interests of the state. Modern approaches to the organization and management of the resource potential of the territory in the direction of its sustainable strategic development are analyzed. The authors substantiate the conditions and factors of formation of the resource potential of the region. On the basis of a detailed study of the problem, the mechanism developed by the authors to implement the strategy of effective use of resource potential at the regional level is presented. The proposed mechanism can be implemented in the socio-economic management of the territory focused on sustainable development.
\end{abstract}

Keywords: sustainable development; resource potential; strategy; territory

Reference to this paper should be made as follows: Voronkova, O.; Yankovskaya, V.; Kovaleva, I.; Epishkin, I.; Iusupova, I.; Berdova, Y. 2019. Sustainable territorial development based on the effective use of resource potential, Entrepreneurship and Sustainability Issues 7(1): 662-673. http://doi.org/10.9770/jesi.2019.7.1(47)

JEL Classifications: Q01, O13, P28 


\section{ENTREPRENEURSHIP AND SUSTAINABILITY ISSUES}

ISSN 2345-0282 (online) http://jssidoi.org/jesi/

2019 Volume 7 Number 1 (September)

http://doi.org/10.9770/jesi.2019.7.1(47)

\section{Introduction}

When implementing a strategy of sustainable territorial development, it is important to achieve a balanced solution to the socio-economic task to preserve and increase the efficiency of using resource potential. Stabilization of the socio-economic situation is associated with centralization of decision-making at the territorial level, as well as the willingness and ability of territories to provide targeted and effective use of all available resources.

The analysis of the concepts of "sustainable development" and "resource potential" suggests that sustainable development of regions with natural-resource specialization implies the efficient use of their natural (and geographical) competitive advantages in the socio-economic development of the Russian Federation.

The broad interpretation of the term "potential" allows applying it in various branches of science and practice, depending on the type of resource, its reserves, and sources. The presented scientific term encompasses two aspects: resource availability and its targeted use. Furthermore, the potential is a combination of all available factors of production, intelligence, production reserves and opportunities that can ensure the release of highquality and in-demand goods and services necessary to meet the comprehensive needs of various categories of consumers (Alferova, 2015; Isyanbaev, 2016; Poltarykhin et al., 2018; Rozenberg, 2005).

At the same time, the potential is not only the amount of a certain resource but also the possibility of developing the system in a given direction, as well as its effective use. Thus, the potential should be understood as a set of funds and reserves of a certain territorial resource, the use of which allows achieving the economic effect. The World Conservation Strategy, presented in 1980 by the International Union for Conservation of Nature and Natural Resources, emphasized that sustainable development requires considering not only economic aspects but also social and ecological ones. In the 1980s, the issue of the relationship between ecology and social development was particularly actively discussed in the global scientific community (Korableva et al., 2018; Gusev, 2013; Danilov-Danilian, 2003; Dokholyan, 2011; Mishenin et al., 2018; Kolesova, 2015). Later, it was replaced by the concept of "eco-development", meaning environmentally friendly development, that is, development that has the least negative impact on the environment.

Most of the international organizations of the UN system have incorporated the substantial environmental component into their activities, oriented towards the transition to sustainable development. The World Bank experts have identified sustainable development as a process of managing a collection (portfolio) of assets aimed at preserving and expanding people's opportunities (Podprugin, 2012; Pavolová et al., 2019; Shumakova et al., 2016; Mikhailushkin et al., 2018). The assets in this definition include not only traditionally considered financial and material capital but also natural and human capital.

\section{Methodology}

The study is based on the study of sustainable development based on the integrated and effective use of territorial resource potential, the formation of organizational and economic relations of sustainable development, including through the mechanism for achieving the goals of sustainable territorial development through the effective use of resource potential. To achieve the objectives of the study, the authors used a critical analysis of literary sources, as well as general scientific methods - the system approach, the methods of analogies, abstract, logical, monographic, statistical and economic methods. The system approach served as a methodological basis, which allowed ensuring the complexity and focus of the study. 


\section{ENTREPRENEURSHIP AND SUSTAINABILITY ISSUES}

ISSN 2345-0282 (online) http://jssidoi.org/jesi/

2019 Volume 7 Number 1 (September)

http://doi.org/10.9770/jesi.2019.7.1(47)

\section{Results and Discussion}

Synthesizing the existing approaches to understanding the category of "sustainable development" allows distinguishing two major interpretations of this concept. The first one focuses attention mainly on the environmental component, which is reflected in the optimization of the territory's activity towards the biosphere. The second one implies a new type of territorial development based on significant changes in its historically established parameters: economic, social, ecological, tourist and recreational, cultural, etc. Thus, the "concept of sustainable territorial development" is multidimensional and consists of several interrelated aspects, including:

- the economic aspect directs the territory's production and economic activity not to the increase in consumption of natural resource potential, but to its effective use;

- $\quad$ the social aspect implies an increase in the earned income of the population by reducing poverty and improving the quality of life in the region;

- $\quad$ the environmental aspect assumes a strict regulation of environmental management and environmental protection;

- $\quad$ the cultural aspect determines the set of historically established characteristics of the territory and national composition of the population;

- $\quad$ the prognostic aspect is associated with considering not only the current sustainable development strategy but also the assessment of long-term planning dynamics.

Russia's transition to sustainable development was presented by the Government of the Russian Federation and approved by the decision of the President of the Russian Federation in April 1996. The concept involves the formation of the effective spatial structure of the country's economy while respecting the balance of interests of all subjects of the Russian Federation (Sycheva et al., 2017; Voronkova et al., 2018; Telyakov et al., 2016; Ivanova et al., 2018). The analysis of the presented concept shown that considered attention is paid to the regional aspect, justified the possibility of transition to sustainable development of the Russian Federation under the condition of sustainable development of its territories (Fedorinin and Zhuravlev, 2002; Nechaev et al., 2018a,b). We believe that this is possible only in the formation of an effective spatial structure of the country's economy and the balance of interests of all subjects of the Russian Federation.

The process of transition of the regional economy to sustainable development is associated with its stabilization, which, based on the research methodology, is objectively related, on the one hand, to the general content of the ongoing economic transformations in the country, and on the other hand, to the objective socio-economic situation in a certain territory. The implementation of this process should be based on the economic reality of the territory; it is important to consider the potential of this territory, its socio-economic specifics, and cultural characteristics. Therefore, the major methodological principles for the study of sustainable development of the territory are the following:

- the principle of unity of the territory's economic development and the process of the national economy reformation;

- the principle of a single financial and economic space of the state in implementing economic development at the territorial level;

- $\quad$ the principle of diversity in implementing sustainable development of the territory.

When using natural resources in production, in some cases economists proceed from the concept called "The Theory of Three Factors", where each production factor is considered a separate source potentially contributing to income growth (Kovalenko, 2012; Malarev et al., 2018; Makar, 2015; Asaliev et al., 2014; Mikhailushkin et al., 2018). So, invested capital brings interest, labor - produced goods, land - product and rent. The interchangeability of resources helps to reduce the scarcity of certain types of raw materials, which are often dependent on each other. Modern economics provides opportunities for accounting for various alternative solutions differentiating in capital intensity of mining and development, the service life of raw materials sources and return on investments, as well as the assessment of environmental damage. 


\section{ENTREPRENEURSHIP AND SUSTAINABILITY ISSUES}

ISSN 2345-0282 (online) http://jssidoi.org/jesi/

2019 Volume 7 Number 1 (September)

http://doi.org/10.9770/jesi.2019.7.1(47)

Definition of conditions, factors, and prerequisites for sustainable territorial development is closely linked to the assessment of its resource and environmental potential. The value of the natural resource potential as the sum of potentials of individual types of territory's natural resources (land, water, forest, mineral resource base) depends on the following factors:

- $\quad$ the list of available natural resources (the more resources to be used in the production process, the higher the level of resource potential) (Petukhov et al., 2017; Aleksandrova et al., 2019; Gulkov et al., 2019);

- $\quad$ quantitative characteristics of certain types of resources (value of stocks, share, and terms of their exhaustion);

- $\quad$ qualitative characteristics (the content of useful substance, caloric value, availability);

- $\quad$ the possibility of the systematic use of resources.

One of the major activities of regional authorities and local governments is the rational use of primary and secondary resources, the restoration of renewable natural resources, improving the quality of environmental components and residential security in the territory.

Currently, there is no consensus on the (Goloshchapova et al., 2018). At the same time, despite the enormous achievements of science and technology, the primary types of natural resources in Russia remain solar energy, internal heat, water, land, mineral, plant and animal resources. Depending on the state and level of productive forces development, nature is affected by society, which, objectively, can be both positive and negative.

A number of scientists, analyzing the strategy of socio-economic development of the Russian Federation, note that sustainable territorial development on the basis of resource potential involves improving the efficiency of the use of territorial resources (Yarlykapov, 2013; Shedko, 2015; Darin and Telyakov, 2017; Koptev et al., 2018; Usmanova, 2014), namely:

- $\quad$ ensuring the legal framework for the production and natural complexes in the territory;

- $\quad$ preserving natural resource potential and improving the ecological condition of the territory;

- $\quad$ organizing complex environmental monitoring;

- $\quad$ developing a methodological framework for environmental regulation and environmental auditing.

Therefore, the study of the regional natural resource potential is a prerequisite for creating an effective management system in the national economy. The quantitative and qualitative characteristics of natural resources determine the specialization of different economic regions, the prospects for their infrastructure development, as well as the capacity and spatial dimensions of local markets.

The most effective use of the resource potential is of great importance for the stable territorial development of territories. The importance of strategic resource management for a territory results from the fact that it is the resources of various types that underlie the creation of such important elements of national wealth as fixed assets. Furthermore, the resources are directly involved in shaping the characteristics of socio-economic territorial development (Shatunova et al., 2019), which include the gross domestic product, the amount of investment attracted to this territory, the high standard of living and employment.

The resources are a multifaceted category, including all factors of activity (tangible and intangible), which allow the territory to perform any activities within the framework of a predetermined development strategy (Vinogradova, 2013; Prodanova et al., 2019a; Yemelyanov et al., 2018; Sharafutdinov et al., 2019; Nagimov et al., 2018; Amraoui et al., 2019). The resource potential is the possibility of using the resources available in a given territory to obtain any beneficial effects. When developing a sustainable development strategy based on the resource potential of a territory, it is necessary to consider that its natural, climatic, economic, informational, infrastructural, socio-cultural, demographic and other conditions have been formed and acted in the territory for a long period of time and therefore, largely determine its current state and territorial development trends. 
Each territory has its own specific list of resources; however, not all the resources of a given territory have equal importance or potential for ensuring sustainable competitive advantages to this territory. To achieve a territorial competitive advantage, the most important are those resources that are endowed with such features as uniqueness, rarity, and the impossibility of substitution. In our opinion, the resource provision of sustainable development of the territory should be controlled by the authorities in the appropriate form and based on clear resource strategies that contribute to the solution of the following tasks (Figure 1).

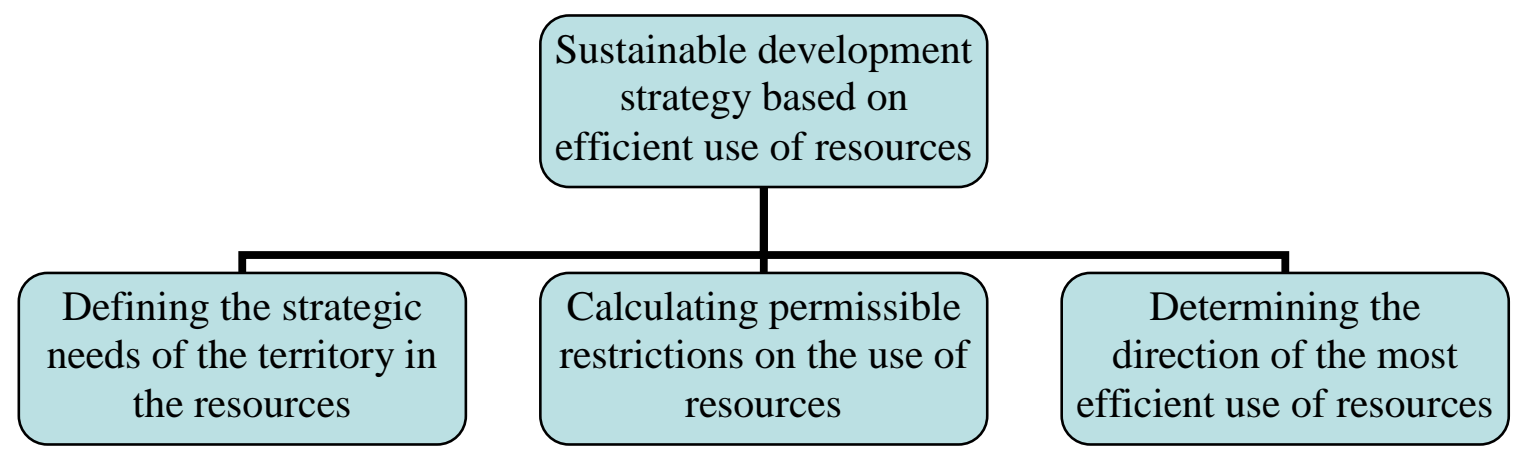

Fig. 1. Resource strategy for sustainable territorial development Source: own research

The achievement of organic interconnection and integration of numerous functional types of production activities developed in this territory (trade, production, tourism) into a single cross-sectoral management system is a characteristic feature of modern approaches to organization and management of territorial resources. The modern approach to improving the efficiency of the region's resource potential implies building a resource strategy basis on studying its competitive position with respect to its internal uniqueness. At the same time, an important emphasis should be placed on defining the characteristics of a resource that allows generating sustainable competitive advantages of the territory. Such a resource must form an economic value, be quite rare, difficult to imitate and difficult to access in the market of production factors (Pikulkin, 2010; Polushkina, 2012; Pavlyuk et al., 2018; Dzhavatov et al., 2018; Prodanova et al., 2019b; Dalevska et al., 2019).

The use of resource concept towards sustainable development of the territory is based on systemic imperatives:

- $\quad$ there are persistent systemic differences in the implementation of control over the resource required for the implementation of the territorial development strategy;

- $\quad$ the difference between the types of resources of a particular territory leads to the formation of differences in the socio-economic results acquired by the territory compared to competing territories;

- $\quad$ each territory tries to increase or maximize these results.

To implement the mechanism of effective use of the territory's resource potential to achieve the goals of sustainable development, the authors suggest systematizing its resources into four groups (Robertson, 2014):

- strategically important strengths;

- strategically important weaknesses;

- strategically not important strengths;

- strategically not important weaknesses.

For each group, it is necessary to formulate rules indicating the efficient use of resources and abilities of the territory. These rules are formalized by the executive authorities in the form of strategic priorities within the system of territorial management. With a shortage of resources, their limited nature, high cost or unavailability at 


\section{ENTREPRENEURSHIP AND SUSTAINABILITY ISSUES}

ISSN 2345-0282 (online) http://jssidoi.org/jesi/

2019 Volume 7 Number 1 (September)

http://doi.org/10.9770/jesi.2019.7.1(47)

the territorial level, it becomes important to consider the resource supply of each element of the territorial development strategy (Polyakova et al., 2018).

It is necessary to remember that the limited resources are constantly increasing, which increases the urgency of the most efficient use of the territory's resource potential. The resource utilization plan must be balanced, clear and logical to ensure the optimal use of the limited resources of the territory. The choice of specific criteria and indicators requires the availability of methods for their formation, considering the characteristics of each specific territory.

Improving the management system of the territory's resource potential requires efforts from both state authorities and local governments. Thus, the effective management of the territory's resource potential is an important task of the territory's socio-economic development, as well as the most important component of the territorial policy. Given the limited budget and other material and financial resources, the territory's inner resource potential can be considered the main resource of territorial development. The search for the most efficient use, further preservation, and an increase of the territorial resource potential is one of the key priorities for the local executive authorities and local governments.

The strategy of strengthening the territorial resource potential and increasing its efficiency involves:

- formation of management, socio-economic, legal and regulatory environment for the implementation of principles of sustainable territorial development;

- developing entrepreneurship, mainly small and medium-sized businesses as the key factor of socio-economic territorial development;

- strengthening the economic integration of the territory through a more efficient realization of its competitive advantage in the form of a unique resource potential;

- promoting active development of the personnel potential through social and demographic stabilization, the achievement of productive employment, and the development of social infrastructure;

- improving the complex of environmental measures and more efficient use of the territory's natural resources.

The main activities of federal and local authorities in the strategy of sustainable development of the territorial resource potential should involve expanding the sectoral specialization of the economy, creating technologically equipped processing enterprises in the territory, cleaner production, developing transport and market infrastructure in the territory, promoting entrepreneurship, implementing innovation policy, ensuring effective management of the territory's infrastructure.

Ensuring the comprehensive human resource development of the territory requires the formation of a set of measures for this direction of development. Among these measures, one can mention the development of social programs aimed at solving the labor problems of the territory (providing employment, creating new jobs, financing the education, health care, social protection and culture sectors) (Ilyina et al., 2019; Korableva et al., 2019; Voronkova et al., 2019; Krasyuk et al., 2018). In the modern world of innovation and rapid technology development, it is also necessary to consider the intangible resources of the territory.

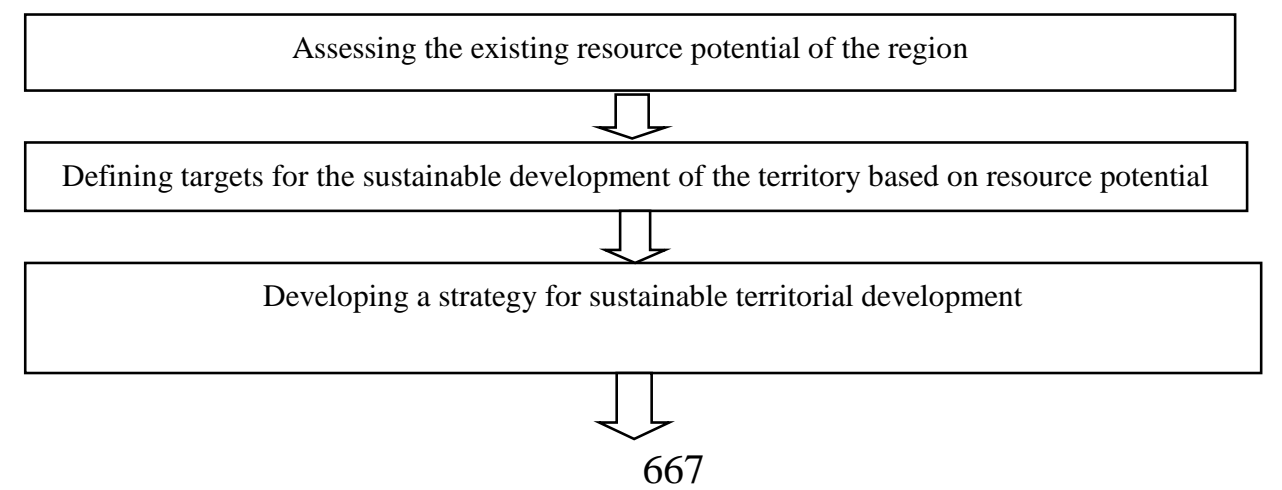


ENTREPRENEURSHIP AND SUSTAINABILITY ISSUES

ISSN 2345-0282 (online) http://jssidoi.org/jesi/

2019 Volume 7 Number 1 (September)

http://doi.org/10.9770/jesi.2019.7.1(47)

\begin{tabular}{|l|l|l|}
\hline \multicolumn{3}{|c|}{ Creating institutional conditions for more effective use of the territory's resource potential in } \\
sustainable development strategy
\end{tabular}

Fig. 2. The mechanism for achieving the goals of sustainable development of the territory through the effective use of resource potential Source: own research

Based on the study of scientific materials on the research topic, it can be concluded that the results of sustainable territorial development depend on many factors, the analysis and evaluation of which is carried out using a systematic approach and system analysis. Initially, the results depend on the quantitative and qualitative characteristics of territorial resources, technologies, internal and external factors. Therefore, the effective use of the resource potential of the territory is an objective condition for the implementation of all functions of the territory and can be considered an essential prerequisite for sustainable territorial development. According to the authors of the article, the implementation of this approach takes place within the framework of the resource concept aimed at the effective implementation of the resource potential of the territory in the conditions of fierce market competition between the territories for strategically important partners, as well as consumers and tourists. Mechanism for achieving the goals of sustainable development of the territory on the basis of effective use of resource potential.

The conditions for the formation of resource potential imply the state of productive forces of society, including natural factors, equipment, and technologies, as well as the educational and qualification competencies of people for their effective use, within a specific territory. The main conditions, varying in different federal districts and regions, include the level of GDP production; the level of real incomes of the population; the volume of investment in the economy, etc. The prerequisites for the effective use of resource potential include the extent to which territorial resources are used correctly and scientifically and how the potential of strategic production is ensured.

The factors forming the economic potential of the region are the key resources of productive activities (land, labor, capital, and entrepreneurship), and the driving force of economic and production processes affecting the result of production and economic activity. The factors affecting labor productivity include the level of remuneration, labor organization, employee training, and technical perfection of production tools.

In general, the regional factors include the economic and geographical location of the territory, its population and labor resources, the industrial complex of the territory, the infrastructure, localized natural resources (energy, mineral, biological, water), transport infrastructure, scientific and technological potential, and other factors. 


\section{ENTREPRENEURSHIP AND SUSTAINABILITY ISSUES}

ISSN 2345-0282 (online) http://jssidoi.org/jesi/ 2019 Volume 7 Number 1 (September) http://doi.org/10.9770/jesi.2019.7.1(47)

\section{Conclusion}

Sustainable development of territorial production largely depends on the resource potential, which includes the territory's geopolitical situation, its socio-political conditions and development factors; natural potential (water, forest, land and mineral resources); demographic and labor potential; production potential (the material and technical base of the territory and financial resources for its development); social potential (health care, education, housing and municipal services, trade, public catering). In most of the socio-economic indicators in the strategies of sustainable development of the Russian territories, the authors revealed noticeable discrepancies caused by differences in the available territorial resources and efficiency of their use. The processes of rapprochement in sustainable territorial development are not automatic; therefore, without an effective regional strategy and policy, it is impossible to mitigate the existing differentiation in terms of the key production indicators of the territory and in terms of development and well-being of its population.

The availability of basic resources of a certain territory is often limited by circumstances of both objective and subjective nature. Modern industrial enterprises generally face a shortage of water, land and mineral resources, energy, and skilled workers. Sustainable development of territorial production is also associated with the effective use and strengthening of its material and technical base, which is one of the crucial components of territorial resource potential in sustainable development strategies.

\section{References}

Alferova T.V. 2015. Conceptual modeling of the category of «sustainable development». Journal of Economic Theory, 4, 46-52. file:///C:/Users/Manuela/Downloads/Sustainable\%20Development\%20of\%20Territories\%20Based\%20on\%20the\%20Integrated\%20Use\% 20of\%20Industry, \%20Resource\%20and\%20Environmental\%20Potential.pdf

Aleksandrova T. N., Nikolaeva N. V., Lvov V. V., Romashev A. O. (2019) Ore processing efficiency improvements for precious metals based on process simulations. Obogashchenie Rud, (2), 8-13. https://doi.org/10.17580/or.2019.02.02

Amraoui, B., Ouhajjou, A., Monni, S., El Amrani El Idrissi, N., Tvaronavičienè, M. (2019). Performance of clusters in Morocco in the shifting economic and industrial reforms. Insights into Regional Development, 1(3), 227-243. https://doi.org/10.9770/ird.2019.1.3(4)

Asaliev, A. M., Zhuravlev, P. V., \& Alkhimenko, O. N. (2014). Intellectual capital management as the aspect of upgrading of modern companies management. Life Science Journal, 11(SPEC. ISSUE 11), 363-366.

Dalevska, N., Khobta, V., Kwilinski, A., Kravchenko, S. (2019). A model for estimating social and economic indicators of sustainable development. Entrepreneurship and Sustainability Issues 6(4): 1839-1860. http://doi.org/10.9770/jesi.2019.6.4(21)

Danilov-Danilian V.I. 2003. Sustainable development. Theoretical and methodological analysis. Economics and Mathematical Methods, 8 (24), 123-135.

Dzhavatov, D. K., Sverdlikova, E. A., Sokolov, M. S., Avdeeva, O. A., \& Yavkin, G. P. (2018). The influence of innovation on social and economic development of the Russian regions. European Research Studies Journal, 21(Special Issue 2), 767-776.

Darin, A. A., \& Telyakov, N. M. (2017). Processing of ferromanganese concretions with the use of sulfatising roasting. Journal of Engineering and Applied Sciences, 12(5), 1113-1115.

Dokholyan A. S. 2011. Problems of sustainable development of the region's economy. Modern problems of science and education, 5, 2531 .

Fedorinin, V. N., \& Zhuravlev, P. V. (2002). New developments of optopolarization sensor devices and articles based on them. Paper presented at the Proceedings of SPIE - the International Society for Optical Engineering, 4900(2) 982-987. http://doi:10.1117/12.484491

Goloshchapova, L. V., Plaskova, N. S., Prodanova, N. A., Yusupova, S. Y., \& Pozdeeva, S. N. (2018). Analytical review of risks of loss of profits in cargo transportation. International Journal of Mechanical Engineering and Technology, 9(11), 1897-1902. 


\section{ENTREPRENEURSHIP AND SUSTAINABILITY ISSUES}

ISSN 2345-0282 (online) http://jssidoi.org/jesi/ 2019 Volume 7 Number 1 (September) http://doi.org/10.9770/jesi.2019.7.1(47)

Gulkov Yu.V., Turysheva A.V., Kopteva A.V. 2019. Research of Grounding Systems of Electrical Complexes in the Conditions of Permafrost Soils. Proceedings of the 2019 IEEE Conference of Russian Young Researchers in Electrical and Electronic Engineering, ElConRus, pp. 969-972. https://doi.org/10.1109/EIConRus.2019.8657119

Gusev Yu. N. 2013. Sustainable development through the prism of corporate social responsibility. Economic systems, 2, $2-4$.

Ilyina, I., Kulibanova, V., \& Teor, T. (2019). Special aspects of master data-based integrated management of region reputation in modern IT environment. Paper presented at the IOP Conference Series: Materials Science and Engineering, 497(1). https://doi.org/10.1088/1757$\underline{899 X / 497 / 1 / 012022}$

Isyanbaev M. N. 2016. Sustainable development of regional socio-economic systems: directions, mechanisms. Humanitarian research, 12, $12-16$.

Ivanova, V. N., Atyukova, O. K., \& Poltarykhin, A. L. (2018). Prerequisites of growth of investment and social attractiveness of the regions of Russia within the framework of implementation of the public-private partnership projects. International Journal of Mechanical Engineering and Technology, 9(11), 2299-2305.

Kolesova Yu. N. 2015.Strategy of sustainable development of rural areas. Young scientist, 8, 392-394.

Koptev V.Yu., Kopteva A.V., Poddubniy D.A. 2019. Increase in Energy Efficiency of Oil and Gas Companies by Perfecting of Management Systems. Proceedings of the 2019 IEEE Conference of Russian Young Researchers in Electrical and Electronic Engineering, ElConRus, pp. 548-552. https://doi.org/10.1109/EIConRus.2019.8657041

Korableva, O., Durand, T., Kalimullina, O., \& Stepanova, I. (2019). Usability testing of MOOC: Identifying user interface problems. Paper presented at the ICEIS 2019 - Proceedings of the 21st International Conference on Enterprise Information Systems, 2468-475.

Korableva, O. N., Kalimullina, O. V., Zaytseva, A. A., \& Larionov, A. I. (2018). Elaboration of database for the subject domain of innovation and economic growth potential. Paper presented at the Proceedings of the 31st International Business Information Management Association Conference, IBIMA 2018: Innovation Management and Education Excellence through Vision 2020, $6065-6073$.

Kovalenko E. G. 2012. Problems and mechanisms of development of rural territories. Fundamental research, 3-3, 687-690.

Krasyuk, I. A., Kobeleva, A. A., Mikhailushkin, P. V., Terskay, G. A., \& Chuvakhina, A. G. (2018). Economic interests focusing as a basis of the formation of investment policy. Espacios, 39(31)

Malarev V.I., Kopteva A.V., Koptev V.Yu. (2018). Electric Power Supply System Development for Down-hole Electric Steam Generators to Produce High-viscosity Oil. International Multi-Conference on Industrial Engineering and Modern Technologies, FarEastCon. https://doi.org/10.1109/FarEastCon.2018.8602954

Makar S. V. 2015. To the question of the pole of development of the region's potential. Pskov regional journal, 24 (24), $12-22$.

Mikhailushkin, P. V., Lubkova, E. M., Shilova, A. E., Zhuravlev, P. V., Karpenko, E. Z., \& Nikiforov, S. A. (2018). Possibilities of agriculture competitiveness increasing. International Journal of Mechanical Engineering and Technology, 9(11), 1401-1412.

Mikhailushkin, P. V., Novoselova, N. N., Shulga, K. V., Kolpak, E. P., \& Kabrits, S. A. (2018). Study of the forms and conditions of economic crises in the regional economies of developing countries. Espacios, 39(31)

Mishenin, Y.; Koblianska, I.; Medvid, V.; Maistrenko, Y. 2018. Sustainable regional development policy formation: role of industrial ecology and logistics, Enterpreneurship and Sustainability Issues 6(1): 329-341. http://doi.org/10.9770/jesi.2018.6.1(20)

Nagimov, A. R., Slanov, V. P., Shpakova, R. N., Solomonov, M. P., \& Il'yaschenko, D. P. (2018). Foresight technologies in the formation of a sustainable regional development strategy. European Research Studies Journal, 21(2), 741-752.

Nechaev, V., Mikhailushkin, P., \& Alieva, A. (2018a). Trends in demand on the organic food market in the european countries. Paper presented at the MATEC Web of Conferences, 212 http://doi:10.1051/matecconf/201821207008

Nechaev, V., Mikhailushkin, P., \& Presnyakov, D. (2018b). Priorities of social and economic safety. Paper presented at the MATEC Web of Conferences, $212 \mathrm{http}: / /$ doi:10.1051/matecconf/201821204015 


\section{ENTREPRENEURSHIP AND SUSTAINABILITY ISSUES}

ISSN 2345-0282 (online) http://jssidoi.org/jesi/ 2019 Volume 7 Number 1 (September) http://doi.org/10.9770/jesi.2019.7.1(47)

Pavlyuk, A. V., Hasanov, E. L., Sverdlikova, E. A., \& Kadyrov, M. A. (2018). Institutional mechanisms for implementation of entrepreneurial potential of the population of the region. Journal of Applied Economic Sciences, 13(7), 2052-2075.

Pavolová, H., Bakalár, T., Emhemed, E. M., Hajduová, Z., Pafčo, M. 2019. Model of sustainable regional development with implementation of brownfield areas, Entrepreneurship and Sustainability Issues 6(3): 1088-1100.

Petukhov, A. A., Dar'in, A. A., \& Telyakov, N. M. (2017). Processing of ferromanganese nodules of the Pacific Ocean. Metallurgist, 61(56), 439-443. https://doi.org/10.1007/s11015-017-0514-9

Pikulkin A.V. 2010.The system of government administration. - Moscow: UNITY-DANA, 639.

Podprugin M. O. 2012. Sustainable development of the region: the concept, the basic approaches and the factors. Journal of Russian entrepreneurship, 24, 214-221.

Poltarykhin A.L., Alekseev A.E., Kudryavtsev V.V., Makhanova T.A., Voronkova O.Yu., Aydinov H.T. 2018. Prospects for the Development of the Green Economy of Russian Federation. European Research Studies Journal Volume XXI, Issue 4, pp. 470-479.

Polushkina T. M. 2012. Formation of a rational system of state regulation of agrarian sector of economy meeting the requirements of costeffective agricultural policy. Basic research, 9-4, 976-980.

Polyakova, A. G., Goloshchapova, L. V., Rakhmeeva, I. I., Noeva, E. E., \& Rakovskiy, V. I. (2018). A model of regional economic space modernization. European Research Studies Journal, 21(Special Issue 2), 624-634.

Prodanova, N. A., Trofimova, L. B., Adamenko, A. A., Erzinkyan, E. A., Savina, N. V., \& Korshunova, L. N. (2019a). Methodology for assessing control in the formation of financial statements of a consolidated business. International Journal of Recent Technology and Engineering, 8(1), 2696-2702.

Prodanova, N. A., Plaskova, N. S., Bochkareva, N. G., Babalykova, I. A., Gazizyanova, Y. Y., \& Zherelina, O. N. (2019b). Integrated Corporate Reporting as An Innovative Business Reporting Model. International Journal of Engineering and Advanced Technology, 8(5), 2075-2078.

Robertson St., Blackwell B. 2014. Lifecycle Planning and Enduring Value for Remote communities. International Journal of Rural Law and Policy, 1, $1-11$.

Rozenberg N.V. 2005. Socio-cultural component of the concept «region». Analytics of cultural science, 2(4), 34-43.

Sharafutdinov, R. I., Polyakova, A. G., Gerasimov, V. O., Shpakova, R. N., \& Mikhailova, M. V. (2019). Inclusive growth: A dataset on key and institutional foundations for inclusive development of Russian regions. Data in Brief, 23. https://doi.org/10.1016/j.dib.2019.103864

Shatunova O., Anisimova T., Sabirova F., Kalimullina O. (2019) STEAM as an Innovative Educational Technology. Journal of Social Studies Education Research, 10 (2), 131-144.

Shedko Yu. N. 2015. A set of mechanisms for managing sustainable development of regions. Economics and management: problems, solutions, 8(44), 92-97.

Shumakova, O., Poltarykhin, A. L., \& Mozzherina, T. G. (2016). Import substitution as the basis of solving problem related to food safety of the russian federation. International Journal of Applied Business and Economic Research, 14(9), 5911-5920.

Sycheva, I.N., Ovchinnikov, Y.L., Permyakova, E.S., Voronkova, O.Yu. 2017. Organic Production at Long-fallow Lands as a Strategic Resource of the Food Import Substitution Policy. Revista Espacios, 38(33), 40.

Telyakov, N. M., Darin, A. A., Telyakov, A. N., \& Petukhov, A. A. (2016). Influence of the specific character of the content of ironmanganese concretions of the Pacific Ocean and Baltic Sea on technological indicators of valuable component extraction. Tsvetnye Metally, (2), 40-45. https://doi.org/10.17580/tsm.2016.02.06

Usmanova T. H. 2014. Modern requirements of formation of strategy of social and economic development of regions. Economy. Business. Banks, 2(7), 23-36.

Vinogradova K. O. 2013. The essence and structure of the development potential of the region. Modern problems of science and education, 3(18), 17-25. 


\section{ENTREPRENEURSHIP AND SUSTAINABILITY ISSUES}

ISSN 2345-0282 (online) http://jssidoi.org/jesi/ 2019 Volume 7 Number 1 (September) http://doi.org/10.9770/jesi.2019.7.1(47)

Voronkova, O. Y., Akhmetshin, E. M., Sycheva, I. N., Shpakova, R. N., Pashkova, E. Y., \& Poltarykhin, A. L. 2018. Economic mechanism of regulating land relations in the agricultural sector of Russia. European Research Studies Journal, 21(4), 280-291.

Voronkova, O. Y., Iakimova, L. A., Frolova, I. I., Shafranskaya, C. I., Kamolov, S. G., \& Prodanova, N. A. (2019). Sustainable development of territories based on the integrated use of industry, resource and environmental potential. International Journal of Economics and Business Administration, 7(2), 151-163.

Yarlykapov A. D. 2013. Assessment of regional development forecasting options. Regional economy, 2 (34), $23-31$.

Yemelyanov, V., Tochilkina, T., Nedelkin, A., \& Shved, E. (2018). Automation of monitoring and diagnosing the technical condition of torpedo ladle cars. Paper presented at the MATEC Web of Conferences, 239 https://doi.org/10.1051/matecconf/201823904003

Olga VORONKOVA, doctor of Economics, Professor of management, business organization and innovation Department, Altai state University. Has the status of an expert of the Eurasian technological platform "Technologies of food and processing industry of agriculture - healthy food". Research interests - sustainable development of territories, innovation, technological and social entrepreneurship, "green" economy.

ORCID ID: https://orcid.org/0000-0002-3106-4643

Veronika YANKOVSKAYA, Candidate of Economic Sciences, Associate Professor, Senior Researcher of the Higher School of Tariff Regulation of Plekhanov Russian University of Economics (PRUE); State University of Management (GUU): Department of Industrial Management. The editorial expert of the portal Seychas.ru news stories from the field of economics and management since 2017. She has the professional experience of a consultant: Specialist of the strategic analysis department of Volga-Dnepr Airlines; Expert, Consulting Department, Unicon; Analyst, Department of Federal and Regional Programs, Compulink. Research interests: Reforming the systems and structures of enterprise management. Development and implementation of the strategy. Problems of theory and practice of management, management development model. Humanization of labor of teaching staff (effectiveness and efficiency of teaching staff. Capacity of teaching staff). Information Security.

ORCID ID: https://orcid.org/0000-0003-3614-2169

Irina KOVALEVA, Dr. SC. (Econ.), Professor, Department of management, Altay State Agrarian University. Research interests: Development of region and Agricultural brunch, Marketing research, logistics.

ORCID ID: orcid.org/0000-0002-3184 5642

Ilya EPISHKIN. Ph.D., associate professor, head of the department "Labor Economics and Human Resource Management" Russian University of Transport.

ORCID ID: https://orcid.org/0000-0001-5952-0164 


\section{ENTREPRENEURSHIP AND SUSTAINABILITY ISSUES}

ISSN 2345-0282 (online) http://jssidoi.org/jesi/ 2019 Volume 7 Number 1 (September) http://doi.org/10.9770/jesi.2019.7.1(47)

Iuliana IUSUPOVA, Candidate of Medical Sciences. Director at the multidisciplinary medical clinic LLC "MedLife" (Moscow). She is writing a thesis for the degree of Doctor of Medical Sciences on the topic: "The basic principles and methods of individual programming of the properties of biofilm gingival sulcus and paradontal pockets in the prevention and treatment of inflammatory diseases of paradont. Research interests: Medicine, Dentistry, Biomedical Chemistry, Biochemistry, Biology and Medicine, Nutritional Issues, Microbiology, Epidemiology and Immunobiology, Clinical Laboratory Diagnostics, Clinical Medicine, Molecular Biology, Molecular Genetics, Microbiology and Virology, Morphology, Applied Biochemistry and Microbiology.

ORCID ID: https://orcid.org/0000-0001-8610-5652

Yulia BERDOVA, Senior Lecturer, Department of Business-Informatics and Mathematics, Industrial University of Tyumen, Master of Business Informatics. Research interests: information technology, mathematical methods, sociology of management, business and management.

ORCID ID: https://orcid.org/0000-0002-4269-6662

Register for an ORCID ID:

https://orcid.org/register

Copyright (C) 2019 by author(s) and VsI Entrepreneurship and Sustainability Center

This work is licensed under the Creative Commons Attribution International License (CC BY).

http://creativecommons.org/licenses/by/4.0/

c) (1) Open Access 